\title{
Article \\ Study of Forage Quality of Grasslands on the Southern Margin of the Pannonian Basin
}

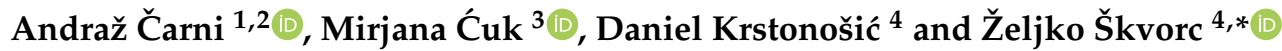 \\ 1 Research Centre of the Slovenian Academy of Sciences and Arts, Institute of Biology, Novi trg 2, \\ 1000 Ljubljana, Slovenia; andraz.carni@zrc-sazu.si \\ 2 School for Viticulture and Enology, University of Nova Gorica, Vipavska 13, 5000 Nova Gorica, Slovenia \\ 3 Department of Biology and Ecology, Faculty of Science, University of Novi Sad, Trg Dositeja Obradovića 2, \\ 21000 Novi Sad, Serbia; mirjana.cuk@dbe.uns.ac.rs \\ 4 Department of Forest Genetics, Dendrology and Botany, Faculty of Forestry and Wood Technology, \\ University of Zagreb, Svetošimunska 25, 10000 Zagreb, Croatia; dkrstonosic@sumfak.hr \\ * Correspondence: zskvorc@sumfak.hr
}

Citation: Čarni, A.; Ćuk, M.;

Krstonošić, D.; Škvorc, Ž. Study of Forage Quality of Grasslands on the Southern Margin of the Pannonian Basin. Agronomy 2021, 11, 2132 https://doi.org/10.3390/ agronomy11112132

Academic Editor: Karoly Penksza

Received: 10 September 2021

Accepted: 21 October 2021

Published: 25 October 2021

Publisher's Note: MDPI stays neutral with regard to jurisdictional claims in published maps and institutional affiliations.

Copyright: () 2021 by the authors. Licensee MDPI, Basel, Switzerland. This article is an open access article distributed under the terms and conditions of the Creative Commons Attribution (CC BY) license (https:// creativecommons.org/licenses/by/ $4.0 /)$.
Abstract: Since grasslands provide many ecosystem services, there are often different opinions on their management (e.g., agronomy, ecology, botany). Multidisciplinary research on this topic is therefore needed. This article focuses on the impact of ecological conditions, functional groups, ecological strategies, floristic composition (through habitat preference of species), major floristic gradients (presented as first two NMDS axes), and the management on forage quality. We estimated the forage quality using indicator values. All of the available vegetation plots in the region on wet and mesic meadows, managed pastures, and tall-herb meadow/pasture fringes on deeper or shallower soils (i.e., grasslands) were collected, organized in a database, and elaborated according to standard procedure. We used a widely accepted grassland classification system that uses floristic composition to define grassland types. Based on an NMDS ordination diagram and according to functional groups, ecological strategies, and habitat preferences (behavior of species) and management, we defined three major groups: mesic meadows (mowed), wet meadows (mowed), and pastures (grazed). We correlated all groups' functional groups, ecological strategies, habitat preferences (behavior of species), major floristic gradients, management, and forage quality. We found that forage quality mainly depends on moisture conditions and that nutrients and grazing are less important. Within the grasslands under consideration, mesic meadows and mesic pastures have the highest forage quality.

Keywords: functional group; ecological strategy; grazing; mowing; vegetation

\section{Introduction}

The category of anthropogenic managed pastures, meadows, and tall-herb meadow fringes on fertile deep soils at low and mid-altitudes of Europe (further on in the text, the term grasslands will be used for all of these vegetation types) includes wet and mesic meadows, managed pastures, and tall-herb meadow/pasture fringes in deeper or shallower soils. This vegetation type is widespread in the study area and is classified according to the Central European method in the class Molinio-Arrhenatheretea [1,2]. These habitats are among the most endangered, and their existence depends on human activities, such as hay production, grazing, or conservation efforts [3,4]. Grassland biodiversity is the result of particular environments and management systems and contributes to the objectives of multifunctional land use systems [5]. As nature protection has a significant impact on the research agenda in recent years, grassland research has shifted from classical floristic and ecological studies to more multidisciplinary and integrated research [4]. Plant biodiversity is often associated with low biomass yield and forage quality, but recent findings do not support this assumption [6].

We estimated the forage quality through the forage indicator values for individual plants that were settled by Briemle and co-workers [7]. They prepared a list of species 
in which they estimated grassland plants on a 9-degree scale, from poisonous to plants with high fodder value. This scale can be used as a basis the estimate the forage quality of grasslands by calculating the weighted mean of plants appearing in an individual grassland [8]. This approach allows estimation of various grasslands on a large scale. It has some limitations in terms of precision (types of livestock, season, management) but enables a rough estimation of grasslands on a large scale. For a detailed study, a more advanced method should be used [9].

A multidisciplinary approach was used in the present research to classify the grasslands in the study area. A large database was based on floristic inventory [10] was elaborated in combination with a functional strategies [11], ecological conditions, and management [12], all which provide a conceptual and methodological framework for the analysis of the relationships among biodiversity, ecological processes, and function, and we tried to evaluate the forage quality of these grasslands using this database. Such integrative research is necessary as we seek solutions and ideas to maintain the balance between economic interests and sustainability [13].

Our research studied the forage quality of grassland habitats from the ecological and functional points of view, but forage quality is also result of multiple other factors, e.g., macroclimate, management, and landscape [14,15], that are, in part, also integrated in the definition of grassland habitats $[3,16,17]$. We tried to establish the correlation between the forage quality and functional trait composition of grasslands since it has been established that the latter is an important predictor of grassland productivity [18].

The aim of the study was to collect all of the available vegetation plot data on grasslands along the southern margin of the Pannonian Plain and to compare grassland types defined according to their biodiversity (floristic composition) and to their functional groups, ecological strategies, ecological conditions, management, and forage quality. We tried to discover the most significant features that correlate to forage quality and evaluate them.

\section{Materials and Methods}

\subsection{Study Area}

The study area extended along the southern margin of the Pannonian Basin, which encompassing the north-eastern part of Slovenia and northern parts of Croatia and Serbia (Figure 1). This area extends from the southern outcrops of the Alps in the west and along the northern margin of the Dinaric Alps to outcrops of the Southern Carpathians. The annual precipitation ranges from $2400 \mathrm{~mm}$ in the west to $530 \mathrm{~mm}$ in the east, and the average annual temperature ranges from $4.1{ }^{\circ} \mathrm{C}$ to $12.1^{\circ} \mathrm{C}$ along the same gradient [19].

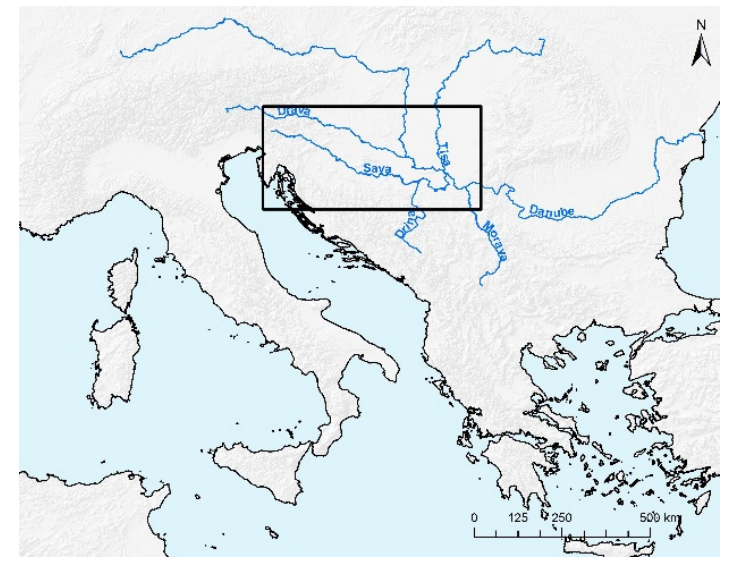

Figure 1. Position of the study area (rectangle) within SE Europe.

\subsection{Data}

The following types of wet to mesic semi-natural grasslands can be found in the region [2]: montane meadows (Triseto-Polygonion bistortae), semi-dry meadows (Salvio 
nemorosae-Arrhenatherion), mesic meadows (Arrhenatherion), mesic pastures (Cynosurion), mesic to wet meadows in the western part of the area (Alopecurion), wet oligotrophic meadows (Molinion), wet eutrophic meadows (Calthion), intermittent wet meadows (Deschampsion), mesic to wet meadows in the eastern part of the area (Trifolion pallidi), salt grasslands (Trifolion-Ranunculion pedati), wet fringe pastures (Mentho longifoliae-Junicion inflexi), wet fringe meadows (Filipendulio-Petasition), and wet pastures (Potentillon anserinae); we eliminated a rather aberrant and scarcely sampled group presenting as the vegetation of forest roads (Alchemillo-Ranunulion repentis). We extracted all of these vegetation types from the publicly available database, the European Vegetation Archive [10]. We obtained a table of 1026 species $\times 2016$ vegetation plots. The majority of the plots date from the second half of the previous century. Grazing and mowing are practiced over the entire region [2]. The plots were sampled during May and at the beginning of June, when plants are in flower, allowing an easy estimation of their cover. After eliminating species that appear in less than $5 \%$ of vegetation plots, the final matrix consisted of 471 species. The elimination did not influence the results significantly [20]. We classified the plots into grassland types as suggested by Škvorc et al. [2] and calculated the constant species in each type. In Table A1, we present the species that occurred in at least $60 \%$ of the vegetation plots of at least one type.

\subsection{Nomenclature}

The taxonomic nomenclature follows that of the Euro+Med Plantbase [21]. The nomenclature of vegetation types is according to Škvorc et al. [2] for grasslands and according to Mucina et al. [1] for other vegetation types.

\subsection{Numerical Analysis}

We calculated the functional composition of the studied vegetation plots through the community-weighted means (CWM) of each trait. This is the average trait value in the vegetation plot that is reflective of the relative abundances of species. Similarly, we used the forage value indicators proposed by Briemle and co-workers [7] since they have been identified as a reliable predictor of plant species selection for cattle [22,23]. We also calculated indicator values that classify grassland species according to their performance in agricultural use: their tolerance to mowing and grazing $[7,24]$. In some cases, the values of species with a Central European distribution were used for their vicariant species in SE Europe that appear in the same ecological conditions. In this way that we obtained data for the forage indicator values for 434 species $(92.1 \%)$ and for data regarding the mowing/grazing for 441 (93.5\%) species.

Because plant functional groups are crucial to ecosystem functioning and because species of the same group have similar strategies to cope with similar environments [25], we calculated the plant functional groups according to plant growth forms that frequently occur in grassland ecosystems, such as grasses, forbs, sedges, legumes, and woody plants [26].

We also calculated ecological strategies, for which we used Grime's model of CSR [27]. This model is based on how plants or plant communities deal with stress and disturbance. Three main strategies can be identified here: those of competitors, stress-tolerators and ruderals, and their combinations. The data were provided by the Biolflora database [28]. The position of each species as well as the positions of communities can be determined in a CSR triangle. The community thus acquires a functional signature [29].

Unweighted Ellenberg indicator values (EIVs) for moisture (EIV Moisture) and nutrients (EIV Nutrients) were calculated using the Juice program [30,31] and were used for the ecological interpretation of the vegetation pattern [31].

We also calculated habitat preferences of different species (behavior), which were estimated according to the accepted phytosociological placement of each species in the syntaxonomic system [1]. The floristic structure in an individual grassland type reflects ecological conditions, dynamics, and relationship within the community [32]. We considered the following types: species of wet and mesic grasslands (Molinio-Arrhenatheretea), 
species of weed and ruderal habitats (Artemisietea, Chenopodietea, Digitario-Agrostietea, Mulgedio-Aconitetea, Parietarietea, Polygono-Poetea annuae, Sisymbrietea), species belong to a humid environment (Bidentetea, Isoeto-Nanojuncetea, Littorelletea, Montio-Cardaminetea, Phragmitetea, Scheuzerio-Caricetea), species belonging to salt habitats (Crithmo-Staticetea, FestucoPucinellietea, Juncetea maritimi, Saginetea maritimae), species belonging to dry grasslands (Calluno-Ulicetea, Coynephoretea, Elyno-Seslerietea, Festuco-Brometea, Helianthemetea, Nardetea, Ononidetea striati, Sedo-Scleranthetea, Stipo-Agrostietea, Stipo-Trachynietea, Thlaspietea), and species belonging to forests and their successional series (Alno-Populetea, BrachypodioBetuletea, Carpino-Fagetea, Epilobietea, Franguletea, Quercetea pubescentis, Rhamno-Prunetea, Robinietea, Trifolio-Geranietea).

We examined the relationships among floristic composition, functional groups, tolerance to mowing and grazing, EIV Moisture, EIV Nutrients, and forage quality by NonMetric Multidimensional scaling (NMDS) using the Bray-Curtis dissimilarity matrix on square-root-transformed percentage cover values. The first two NMDS axes with passive projection of the variables were created using the R package "vegan" in the R package (https. / / cran.r.r-project.org/web / packages/vegan (accessed on 1 September 2021)), which was created in the Juice program [30]. The forage quality by individual grassland types is presented by box-whiskers plots. Kruskal-Wallis ANOVA and multiple comparisons of the mean ranks were used to identify significant differences in the forage quality among the studied grassland types. Finally, forage quality were correlated to EIV Nutrients, EIV Moisture, functional groups, ecological strategies, the habitat preference of species (behavior), and management (tolerance to mowing and grazing) using the Spearman correlation $(p<0.001)$. The latter analyses were conducted in the Statistica program [33].

\section{Results}

\subsection{Ordination with Projected Growth Forms, Tolerance to Mowing, Grazing and EIV Moisture, Nutrients}

We calculated the NMDS and plotted the first two axes on the graph with passive projected forage quality, functional groups, mowing and grazing tolerance, and EIV Moisture and Nutrients (Figure 2). It can be seen that the first axis reflects the correlation with forage quality, functional groups, and EIV Moisture. The second axis reflects the correlation with grazing tolerance and EIV Nutrients.

Three groups of grasslands can be identified in the ordination plane (Figure 2). To the first group, we can assign mesic meadows in the broader sense: mesic meadows in a strict sense (number 2 in the ordination plane), semi-dry meadows (number 1), mesic to wet meadows in the eastern (9) and western part of the area (4) and montane meadows (6); and salt grasslands (10) are transitional to pastures. The second group consists of pastures in the broader sense: mesic pastures (3), wet pastures (13), and wet fringe pastures (11), and the third group consists of wet meadows in the broader sense: wet oligotrophic meadows (5), wet eutrophic meadows (7), intermittent wet meadows (8), and wet fringe meadows (12).

Mesic meadows in the broader sense and mesic pastures have the highest forage quality. These communities are built of a high proportion of grasses and legumes and grow on the driest sites among all of the grassland types. They share good tolerance to mowing. Pastures are built of grazing-tolerant species and occur on nutrient-rich sites. Wet meadows are composed of a high proportion of sedges and forbs; they are the most sensitive to mowing and grazing and occur on the wettest sites. 


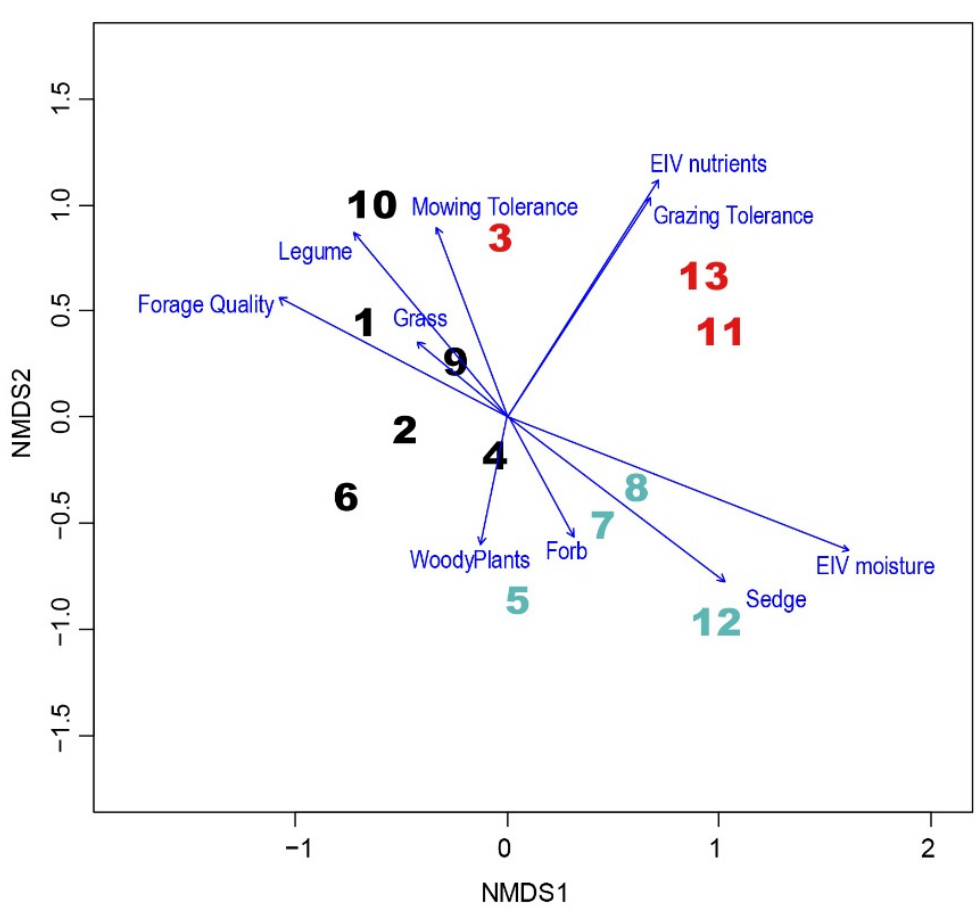

Figure 2. Ordination diagram of non-metric multidimensional scaling (NMDS) of vegetation plots with passively projected forage quality, growth forms, tolerance to mowing and grazing, EIV Moisture, and EIV Nutrient. NMDS stress is 0.2027. Legend: 1-semi-dry meadows (Salvio nemorosae-Arrhenatherion); 2-mesic meadows (Arrhenatherion); 3-mesic pastures (Cynosurion); 4 - mesic to wet meadows in the western part of the area (Alopecurion); 5-wet oligotrophic meadows (Molinion); 6-montane meadows (Triseto-Polygonion bistortae), 7-wet eutrophic meadows (Calthion); 8-intermittent wet meadows (Deschampsion); 9-mesic to wet meadows in the eastern part of the area (Trifolion pallidi); 10—salt grasslands (Trifolion-Ranunculion pedati); 11-wet fringe pastures (Mentho longifoliae-Junicion inflexi); 12-wet fringe meadows (Filipendulio-Petasition) and 13-wet pastures (Potentillon anserinae). We indicated pastures in red, mesic meadows in black, and wet meadows in blue.

\subsection{Ecological Strategies}

The ecological signatures of the grassland types are based on the ecological strategies of the species and show how species or plant communities cope with stress and disturbance (Figure 3). It can be seen that the most disturbed (near the R angle) are wet pastures (13), salt grasslands (10) and mesic pastures (3) and that the least disturbed are wet fringe meadows (12). The most stressful conditions (near the $S$ angle) are in salt grasslands (10) and wet pastures (13) as well as wet meadows in the broader sense, oligotrophic (5), intermittent (8), and eutrophic wet meadows (7); the least stressful conditions are in semidry (1) and mesic (2) meadows. The most favorable conditions (near angle C) are for wet fringe meadows (12), semi-dry (1) and mesic (2) meadows, and wet fringe pastures (11), and least favorable conditions are in salt grasslands (10) and wet pastures 13).

\subsection{Correlations}

We attempted to correlate the forage quality to EIV Moisture, EIV Nutrients, species habitat preferences (behavior), functional groups, and ecological strategies (Table 1). The forage quality is highly positively correlated with mowing and negatively correlated with EIV Moisture as well as with the proportion of stress tolerators and sedges in terms of floristic composition. 


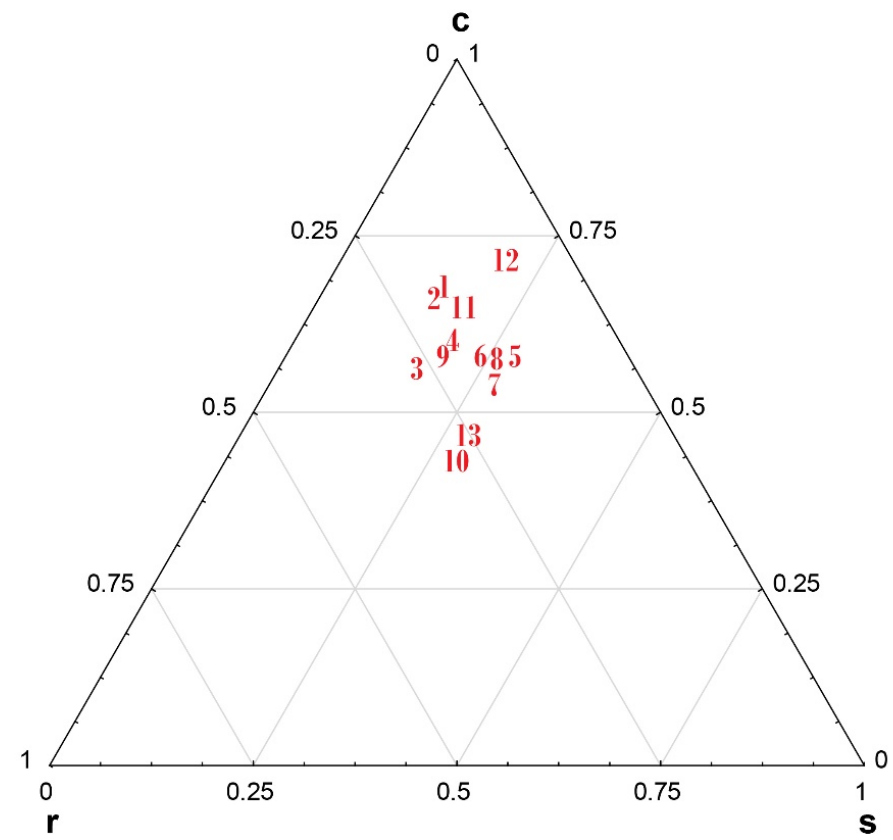

Figure 3. Functional signature of grassland types. Diagram with ecological strategies: competitor (indicated as c), stress-tolerator (s), and ruderal (r). (According to [27,29].) Legend: numbers correspond to those in Figure 2.

Table 1. Spearman rank order correlations of forage quality with EIV Nutrients, EIV Moisture, habitat preference of species, functional groups, ecological strategies, and management. Only correlations that meet criterion $p>0.001$ are presented.

\begin{tabular}{|c|c|}
\hline Variable & Forage Quality \\
\hline EIV Moisture & -0.67 \\
\hline EIV Nutrients & - \\
\hline \multicolumn{2}{|c|}{ Species with the following habitat preferences (behavior) } \\
\hline grasslands & 0.27 \\
\hline forests and their successional series & -0.26 \\
\hline dry grasslands & 0.28 \\
\hline weed and ruderal habitats & 0.55 \\
\hline saline habitats & - \\
\hline humid environment & -0.73 \\
\hline \multicolumn{2}{|c|}{ Functional groups } \\
\hline grasses & 0.51 \\
\hline sedges & -0.61 \\
\hline legume & - \\
\hline forbs & -0.36 \\
\hline \multicolumn{2}{|c|}{ Ecological strategies } \\
\hline c (competitor) & 0.34 \\
\hline $\mathrm{s}$ (stress tolerator) & -0.63 \\
\hline r (ruderal) & - \\
\hline \multicolumn{2}{|c|}{ Management } \\
\hline Mowing & 0.75 \\
\hline Grazing & - \\
\hline
\end{tabular}




\subsection{Forage Quality of Individual Meadow Types}

The box-whiskers diagram (Figure 4) shows that mesic meadows and pastures (number 3 and 2 in Figure 4) possess the highest forage quality; then, there is a group of mesic to wet meadows spanning from the eastern and western parts of the research area $(9,4)$. Next, there are semi-dry meadows and montane meadows $(1,6)$ followed by salt grasslands and wet pastures $(10,13)$ and then intermittent, eutrophic, and oligotrophic wet meadows $(8,7$, 5). Finally, wet fringe pastures and meadows are represented $(11,12)$.

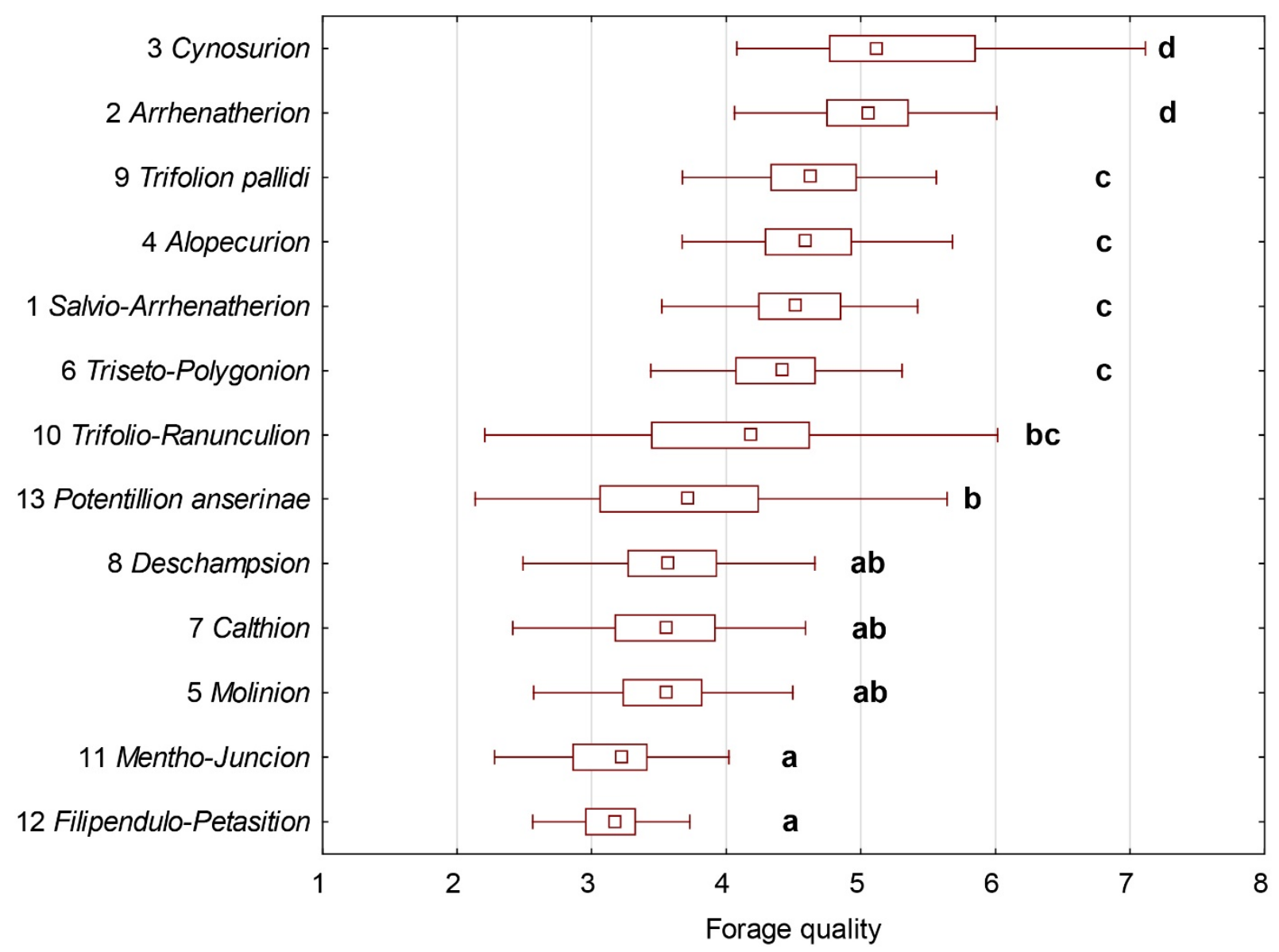

Figure 4. Box-whiskers diagram of forage quality of individual grassland types with multiple comparison of mean ranks (the same letter means that there is no significant difference). Legend is the same as in Figure 2.

\section{Discussion}

The ordination diagram (Figure 2) shows that vegetation plots can be assigned to three groups of grassland types: mesic and wet meadows and pastures. A similar grassland classification has been proposed in Poland based on plant traits [34]. The accepted classification scheme often distinguishes among six groups of grasslands in the region: (1) montane meadows, (2) mesic meadows and pastures, (3) wet meadows, (4) mesic to wet meadows under the influence of a submediterranean climate, (5) wet fringe pastures and meadows, and (6) wet pastures $[1,2,35]$. Perhaps classification based on traits can reveal a new classification scheme, at least on a local scale, since management (i.e., disturbance) is a strong driver of trait differentiation and species coexistence [36]. Such a classification would be closer to the main ecosystem processes than a classification based on floristics since communities may be built up of different species but have similar functional traits and therefore would function similarly. They can thus be unified not by floristic inventory but by function [34]. 
We can divide our material into two principal groups according to grazing and nutrient status (Figure 2) [2]. The first group is composed of pastures that are grazed and trampled and the excrement remains in the major parts within the habitat [32,33]. The transitional position of mesic pastures (group 3) could reflect their transitional character since they can be mown during spring/summer and grazed during summer/autumn [37]. The other group is composed of meadows that are mown, and biomass is completely removed from the habitat. This makes these habitats poorer in nutrients. The further division of meadows corresponds to forage quality and, at the same time, with moisture regime. Meadows can be divided into two groups; mesic meadows that are mown twice/three times a year [38] and wet meadows, which are mown once a year at most (late July-September) or even periodically $[39,40]$. This classification into three groups is similar to that based on plant traits [34].

Grasses have been found to dominate mesic habitats [41], while in wetter site conditions in wet meadows, they are co-dominated by sedges [42]. Tall forbs do not withstand dry conditions and therefore appear more abundantly in wet meadows [43]; some of them (e.g., Succisa pratensis) are even suppressed by mowing [44]. It must be borne in mind that grasses tolerate mowing and grazing better [45]. The higher proportion of N-fixing legumes in mesic meadows has not been confirmed in other studies [41] and requires further investigation.

We found that higher EIV Nutrient is perpendicular to the direction of distinction of mesic and wet meadows, so it can be concluded that nutrients have a small effect on the differentiation of mesic and wet meadows [41]. EIV Moisture shows that mesic meadows appear on drier sites than wet ones and that they are less rarely flooded and/or have deeper ground water [46].

Ecological strategies can be combined in the C-S-R signature, which is useful in comparative studies, also within large geographic areas [47]. Movements in the signature can be used to indicate the degree of resistance, resilience, eutrophication, etc. [29]. In productive, undisturbed habitats, C-type species or "competitors" can be found (e.g., Arrhenatherum elatius, Poa pratensis). These are robust perennials with high potential growth rates that build dense stands with fast-growing biomass above and below ground. Protection from herbivores and the resulting loss of ingested mineral nutrients is a consistent characteristic of S-type species or "stress tolerators". These are slow-growing, stress-tolerant species of chronically unproductive habitats, such as Carex nigra or Limonium gmelinii. R-type species or "ruderals" are found on disturbed sites (e.g., Crepis setosa, Medicago arabica) and are characterized by the early onset of an often-prolonged reproductive phase [27].

Grazing has been found to cause disturbance that favors ruderals with an $\mathrm{R}$ strategy [48]. A shift in the C-S-R signature towards R and S strategies under grazing was therefore noted, and Figure 3 shows that most ruderal species occur on both wet and mesic pastures and salt grasslands $[49,50]$. Salt grasslands occupy a special position within grasslands since many salt-tolerant species (stress-tolerators) appear there, and these habitats are also partially grazed at the same time [51]. Other pastures that do not appear with this group are wet fringe pastures, which are only sparsely grazed [1]. The least amount of ruderals are found in wet fringe meadows that are dominated by Filipendula ulmaria and occur along watercourses and ditches. These habitats are only occasionally mown to stop the succession process [52]. The last two have hardly any economic value (Figure 4). The highest proportion of stress-tolerators is within wet meadows: oligotrophic, eutrophic, and intermittent, as well as within wet pastures and the salt grasslands mentioned earlier. This is consistent with other studies, which have observed a lower proportion of stress-tolerators on drier sides along a hydrological gradient [46]. The highest proportion of competitors was within semi-dry and mesic meadows and the already mentioned wet fringe meadows and pastures.

Correlation with the first two NMDS axes (Table 1) shows that the highest correlation along the first axis is EIV Moisture and forage quality, while the second axis is strongly correlated with grazing and EIV Nutrients. This is consistent with recent research that 
has found that fertilization accounts for about $20 \%$ of the variability in forage quality, and changes in yield and botanical composition explain about $50 \%$ of the fertilization effect $[53,54]$. At the same time, it must be taken into account that when nutrients are widely available, other variables could be the limiting factors [55].

This correlation confirms our previous findings [2] (Table 1). The forage quality correlates with moisture (negatively), a higher proportion of species from grasslands, dry grasslands, and weed and ruderal species. As functional groups, the highest proportion possess grasses and competitors as an ecological strategy.

Grasslands encompass a wide range of habitats that possess different biodiversity and functionality [56]. During the last few centuries, there has been widespread habitat loss resulting from agricultural intensification. The agriculture that was introduced into these areas was primarily orientated towards productivity among other also towards high forage quality [57]. This caused the abandonment of wet meadows, which were converted into mesic meadows with high productivity (forage quality) [58]. Policies that have contributed to these changes have been revisited in recent times and are orientated towards sustainability and contribute to a multi-functional land-use system [59]. However, the restoration process takes a long time [60].

\section{Conclusions}

The article brings a multidisciplinary approach to the elaboration of grasslands and their forage quality in relation to their floristic composition, functionality, ecological conditions, and management. It was found out that forage quality highly correlates with humidity, the proportion of weed and ruderal species, the proportion of sedges and stress tolerant species, and mowing. Using this approach, we confirmed that plant traits are a good predictor of grasslands productivity [18]. These are economically important habitats with high nature conservation value, providing many ecosystem services [11]. Since opposing opinions about their management often appear among stakeholders [6], it is important to elaborate upon the characteristics of grasslands from different perspectives.

Author Contributions: Conceptualization, A.Č. and Ž.š.; methodology, A.Č. and Ž.̌̌.; software, Ž.š.; validation, D.K. and M.Ć.; formal analysis, Ž.S.s.; investigation, A.Č.; resources, D.K. and M.Ć.; data curation, D.K.; writing—original draft preparation, A.Č. and Ž.Š; writing—review and editing, D.K. and M.Ć.; visualization, D.K.; supervision, D.K. and M.Ć.; project administration, Ž.Š.; funding acquisition, A.Č., Ž.Š. and M.Ć. All authors have read and agreed to the published version of the manuscript.

Funding: This paper resulted from bilateral projects between Serbia and Croatia entitled "Diversity of vegetation of wet meadows in a climatic gradient along the southern edge of the Pannonian Plain", financed by the Ministry of Education, Science and Technological Development of the Republic of Serbia and the Ministry of Science and Education of the Republic of Croatia. A. Čarni was supported by a project of the Slovenian Research Agency (ARRS, P1-0236). M. Ćuk was supported by the Ministry of Education, Science and Technological Development of the Republic of Serbia (grant No. III 43002)".

Institutional Review Board Statement: Not applicable.

Informed Consent Statement: Not applicable.

Data Availability Statement: Data are stored in the European Vegetation Archive (EVA) [http: / / euroveg.org/eva-database (accessed on 1 September 2021)].

Conflicts of Interest: The authors declare no conflict of interest. The funders had no role in the design of the study; in the collection, analyses, or interpretation of data; in the writing of the manuscript; or in the decision to publish the results. 


\section{Appendix A}

Table A1. Synthetic table of vegetation material.

\begin{tabular}{|c|c|c|c|c|c|c|c|c|c|c|c|c|c|}
\hline Group No. & 1 & 2 & 3 & 4 & 5 & 6 & 7 & 8 & 9 & 10 & 11 & 12 & 13 \\
\hline No. of vegetation plot & 109 & 332 & 95 & 341 & 179 & 60 & 130 & 216 & 142 & 68 & 54 & 33 & 257 \\
\hline Pastinaca sativa & 85 & 51 & 8 & 6 & 1 & 5 & 1 & . & 17 & 3 & 7 & 3 & 1 \\
\hline Lolium perenne & 8 & 26 & 97 & 20 & . & 10 & 7 & 2 & 7 & 7 & 20 & . & 30 \\
\hline Trifolium repens & 28 & 33 & 89 & 38 & 6 & 13 & 18 & 24 & 29 & 24 & 52 & . & 59 \\
\hline Taraxacum officinale & 34 & 40 & 89 & 40 & 6 & 15 & 10 & 18 & 43 & 22 & 17 & 3 & 38 \\
\hline Plantago major & 11 & 3 & 61 & 5 & 1 & 5 & 6 & 2 & 6 & . & 24 & . & 47 \\
\hline Cynosurus cristatus & . & 34 & 20 & 90 & 18 & 27 & 44 & 36 & 29 & . & 4 & . & 9 \\
\hline Trifolium patens & 6 & 11 & . & 71 & 10 & . & 38 & 37 & 31 & 4 & 4 & . & 4 \\
\hline Galium verum & 46 & 43 & 2 & 65 & 45 & 55 & 8 & 16 & 53 & 43 & 2 & 9 & 1 \\
\hline Succisa pratensis & . & . & . & 17 & 69 & 3 & 20 & 14 & . & . & 2 & 33 & . \\
\hline Carex panicea & . & 2 & . & 17 & 63 & . & 50 & 25 & . & . & 2 & 6 & . \\
\hline Bellis perennis & 11 & 29 & 40 & 18 & 1 & 93 & 8 & . & 15 & 10 & . & . & 13 \\
\hline Stellaria graminea & 5 & 19 & 6 & 23 & 26 & 93 & 8 & 13 & 37 & 9 & 2 & . & 3 \\
\hline Briza media & 3 & 50 & . & 48 & 47 & 92 & 41 & 16 & 18 & 1 & . & . & . \\
\hline Rhinanthus alectorolophus & 1 & 11 & . & 5 & . & 85 & 3 & 4 & 1 & . & . & . & . \\
\hline Bromopsis erecta agg. & 1 & 12 & . & 1 & . & 78 & . & . & . & 1 & . & . & . \\
\hline Knautia drymeia & 1 & 10 & 1 & 3 & 13 & 78 & 3 & . & . & . & . & . & . \\
\hline Vicia cracca & 8 & 45 & 5 & 19 & 11 & 77 & 5 & 17 & 12 & 1 & . & 33 & 2 \\
\hline Cruciata glabra & 1 & 6 & . & 4 & 25 & 75 & 5 & 1 & 1 & . & . & 6 & . \\
\hline Trifolium alpestre & . & 1 & . & . & . & 73 & . & . & 1 & . & . & . & . \\
\hline Trifolium medium & . & 8 & . & . & . & 73 & . & . & 7 & 3 & . & . & . \\
\hline Galium album & 5 & 21 & 2 & 9 & . & 68 & 4 & 1 & 1 & . & 9 & 18 & 4 \\
\hline Salvia pratensis & 9 & 34 & 2 & 1 & . & 68 & 2 & . & 13 & 4 & . & . & . \\
\hline Leontodon hispidus & 11 & 45 & 7 & 53 & 32 & 67 & 24 & 11 & 17 & . & 2 & . & 3 \\
\hline Luzula campestris & 1 & 26 & . & 31 & 22 & 63 & 5 & 6 & 4 & 9 & . & . & . \\
\hline Avenula pubescens & 4 & 14 & 1 & 4 & 2 & 62 & 1 & 1 & . & . & . & . & . \\
\hline Lysimachia nummularia & 6 & 18 & 4 & 36 & 16 & . & 65 & 58 & 27 & 3 & 28 & 6 & 35 \\
\hline Equisetum palustre & . & 2 & . & 6 & 20 & . & 63 & 10 & 5 & . & 11 & 45 & 1 \\
\hline Deschampsia cespitosa & 1 & 4 & 2 & 23 & 46 & 17 & 24 & 76 & 1 & . & 2 & 24 & 2 \\
\hline Gratiola officinalis & . & 1 & . & 26 & 20 & . & 45 & 71 & 25 & . & 11 & 6 & 13 \\
\hline Juncus effusus & . & 1 & . & 18 & 30 & . & 48 & 64 & 11 & 1 & 20 & 24 & 28 \\
\hline Carex vulpina & 3 & 1 & . & 11 & 4 & . & 23 & 60 & 17 & 4 & 9 & . & 5 \\
\hline Alopecurus pratensis & 20 & 23 & 16 & 44 & 25 & 20 & 9 & 50 & 92 & 57 & 7 & 12 & 8 \\
\hline Poa pratensis & 57 & 53 & 33 & 48 & 17 & 22 & 20 & 31 & 69 & 28 & . & 3 & 8 \\
\hline Trifolium pallidum & . & 1 & . & 1 & . & . & . & . & 68 & . & . & . & . \\
\hline Ranunculus polyanthemos & 50 & 3 & 8 & 1 & 1 & 27 & . & . & 63 & 16 & . & . & 2 \\
\hline Festuca valesiaca & 28 & 2 & 16 & . & 1 & . & . & . & 30 & 91 & . & . & . \\
\hline Podospermum canum & 6 & . & 4 & . & . & . & . & . & . & 65 & . & . & . \\
\hline Bromus hordeaceus & 24 & 14 & 11 & 4 & . & 7 & 4 & 1 & 24 & 62 & . & . & 3 \\
\hline Mentha longifolia & 23 & 2 & 8 & 2 & . & . & 2 & . & 9 & . & 100 & 18 & 6 \\
\hline Juncus inflexus & 1 & . & 2 & 1 & 4 & . & 22 & 4 & 1 & . & 96 & 3 & 12 \\
\hline Filipendula ulmaria & . & 1 & . & 11 & 23 & . & 29 & 17 & . & . & 4 & 100 & 1 \\
\hline Carex acuta & . & 1 & . & 4 & 8 & . & 8 & 23 & . & . & 4 & 67 & . \\
\hline Rorippa sylvestris & 5 & 1 & 9 & 1 & . & . & . & 6 & 13 & 9 & 20 & 3 & 62 \\
\hline Arrhenatherum elatius & 78 & 96 & 11 & 13 & 3 & 58 & 4 & . & 12 & 4 & . & 6 & . \\
\hline
\end{tabular}


Table A1. Cont.

\begin{tabular}{|c|c|c|c|c|c|c|c|c|c|c|c|c|c|}
\hline Group No. & 1 & 2 & 3 & 4 & 5 & 6 & 7 & 8 & 9 & 10 & 11 & 12 & 13 \\
\hline Daucus carota & 67 & 54 & 23 & 67 & 11 & 20 & 9 & 6 & 36 & 25 & 19 & . & 11 \\
\hline Trisetum flavescens & 3 & 81 & 3 & 28 & 3 & 97 & 5 & . & 4 & . & . & . & 1 \\
\hline Rumex acetosa & 20 & 64 & 14 & 65 & 30 & 12 & 35 & 28 & 48 & 1 & . & 15 & 3 \\
\hline Anthoxanthum odoratum & 4 & 57 & . & 80 & 34 & 82 & 58 & 40 & 47 & 29 & . & 3 & . \\
\hline Lychnis flos-cuculi & 7 & 21 & 4 & 66 & 39 & 20 & 59 & 63 & 50 & 4 & 4 & 21 & 2 \\
\hline Betonica officinalis & . & 20 & . & 65 & 72 & 28 & 36 & 33 & 31 & 1 & . & 6 & . \\
\hline Potentilla erecta & . & 6 & . & 26 & 83 & 67 & 29 & 16 & . & 3 & . & 6 & . \\
\hline Galium palustre & . & 1 & . & 25 & 31 & . & 65 & 78 & 7 & . & 17 & 33 & 30 \\
\hline Lysimachia vulgaris & . & 2 & 2 & 11 & 50 & 2 & 61 & 30 & 4 & . & 4 & 73 & 1 \\
\hline Agrostis stolonifera & 6 & 5 & 18 & 28 & 17 & . & 12 & 26 & 11 & 3 & 81 & 21 & 94 \\
\hline Dactylis glomerata & 83 & 85 & 41 & 26 & 17 & 95 & 14 & 1 & 24 & 3 & 17 & 12 & 2 \\
\hline Centaurea jacea agg. & 41 & 81 & 17 & 58 & 51 & 85 & 25 & 24 & 66 & 21 & 7 & 12 & 5 \\
\hline Holcus lanatus & 6 & 74 & 12 & 85 & 53 & 53 & 84 & 53 & 13 & . & 13 & 3 & 5 \\
\hline Leucanthemum vulgare agg. & 28 & 73 & 7 & 76 & 37 & 90 & 32 & 33 & 38 & 4 & . & 6 & 1 \\
\hline Schedonorus pratensis & 19 & 64 & 20 & 81 & 25 & 45 & 56 & 47 & 81 & . & . & 3 & 12 \\
\hline Lotus corniculatus & 46 & 64 & 42 & 62 & 50 & 80 & 22 & 22 & 49 & 10 & 2 & 3 & 11 \\
\hline Prunella vulgaris & 15 & 36 & 26 & 60 & 51 & 60 & 49 & 60 & 23 & 1 & 43 & 3 & 32 \\
\hline Ranunculus repens & 9 & 11 & 26 & 47 & 25 & . & 85 & 85 & 17 & . & 85 & 27 & 53 \\
\hline Lythrum salicaria & 2 & 2 & . & 14 & 41 & 2 & 68 & 63 & 12 & 1 & 33 & 91 & 14 \\
\hline Plantago lanceolata & 38 & 80 & 55 & 89 & 44 & 62 & 70 & 57 & 50 & 34 & 17 & 3 & 25 \\
\hline Trifolium pratense & 72 & 83 & 43 & 90 & 27 & 60 & 60 & 39 & 55 & 29 & 9 & 3 & 12 \\
\hline Ranunculus acris & 6 & 79 & 26 & 90 & 78 & 38 & 69 & 60 & 9 & ${ }^{\circ}$ & 22 & 12 & 7 \\
\hline Achillea millefolium agg. & 76 & 77 & 79 & 44 & 31 & 88 & 6 & 4 & 68 & 63 & 19 & 3 & 13 \\
\hline
\end{tabular}

Plots are arranged by meadow types: 1-semidry meadows (Salvio nemorosae-Arrhenatherion); 2-mesic meadows (Arrhenatherion); 3-mesic pastures (Cynosurion); 4-mesic to wet meadows in the western part of the area (Alopecurion); 5-wet oligotrophic meadows (Molinion); 6-montain mesic grasslands (Triseto-Polygonion bistortae); 7-wet eutrophic meadows (Calthion); 8-intermittent wet meadows (Deschampsion); 9-mesic to wet meadows in the eastern part of the area (Trifolion pallidi); 10-salt grasslands (Trifolion-Ranunculion pedati); 11-wet fringe pastures (Mentho longifoliae-Junicion inflexi); 12-wet fringe meadows (Filipendulio-Petasition); and 13-wet pastures (Potentillon anserinae). Only species that reach at least a constancy of $60 \%$ in an individual group are presented.

\section{References}

1. Mucina, L.; Bültmann, H.; Dierssen, K.; Theurillat, J.-P.; Raus, T.; Čarni, A.; Šumberová, K.; Willner, W.; Dengler, J.; Gavilán García, R.; et al. Vegetation of Europe: Hierarchical floristic classification system of vascular plant, bryophyte, lichen, and algal communities. Appl. Veg. Sci. 2016, 19, 3-264. [CrossRef]

2. Škvorc, Ž.; Ćuk, M.; Zelnik, I.; Franjić, J.; Igić, R.; Ilić, M.; Krstonošić, D.; Vukov, D.; Čarni, A. Diversity of wet and mesic grasslands along a climatic gradient on the southern margin of the Pannonian Basin. Appl. Veg. Sci. 2020, 23, 676-697. [CrossRef]

3. Janssen, A.M.; Rodwell, J.S.; García Criado, M.; Gubbay, S.; Haynes, T.; Nieto, A.; Sanders, N.; Landucci, F.; Loidi, J.; Ssysmak, A.; et al. European Red List of Habitats-Part 2. Terrestrial and Freshwater Habitats; Publication office of EU: Luxembourg, 2016.

4. Herzon, I.; Raatikainen, K.J.; Wehn, S.; Rūsina, S.; Helm, A.; Cousins, S.A.O.; Rašomavičius, V. Semi-natural habitats in boreal europe: A rise of a social-ecological research agenda. Ecol. Soc. 2021, 26, 13. [CrossRef]

5. Hopkins, A.; Holz, B. Grassland for agriculture and nature conservation: Production, quality and multi-functionality. Agron. Res. 2006, 4, 3-20.

6. Schaub, S.; Finger, R.; Leiber, F.; Probst, S.; Kreuzer, M.; Weigelt, A.; Buchmann, N.; Scherer-Lorenzen, M. Plant diversity effects on forage quality, yield and revenues of semi-natural grasslands. Nat. Commun. 2020, 11, 768. [CrossRef]

7. Briemle, G.; Nitsche, S.; Nitsche, L. Nutzungswertzahlen für Gefäßpflanzen des Grünlandes. Schriftr. Für Veg. 2002, 38, 203-225.

8. Kaiser, T.; Ahlborn, J. Long-term vegetation monitoring in the floodplain grasslands of the lower Havel Valley (northeastern Germany) and conclusions for sustainable management practices. J. Nat. Conserv. 2021, 63, 126053. [CrossRef]

9. Allen, V.G.; Batello, C.; Berretta, E.J.; Hodgson, J.; Kothmann, M.; Li, X.; McIvor, J.; Milne, J.; Morris, C.; Peeters, A.; et al. An international terminology for grazing lands and grazing animals. Grass Forage Sci. 2011, 66, 2-28. [CrossRef]

10. Chytrý, M.; Hennekens, S.M.; Jiménez-Alfaro, B.; Knollová, I.; Dengler, J.; Jansen, F.; Landucci, F.; Schaminée, J.H.J.; Aćić, S.; Agrillo, E.; et al. European Vegetation Archive (EVA): An integrated database of European vegetation plots. Appl. Veg. Sci. 2016, 19, 173-180. [CrossRef] 
11. Zhao, Y.; Liu, Z. Grassland ecosystem services: A systematic review of research advances and future directions. Landsc. Ecol. 2020, 35, 793-814. [CrossRef]

12. Pittarello, M.; Lonati, M.; Gorlier, A.; Perotti, E.; Probo, M.; Lombardi, G. Plant diversity and pastoral value in alpine pastures are maximized at different nutrient indicator values. Ecol. Indic. 2018, 85, 518-524. [CrossRef]

13. Kun, R.; Babai, D.; Csathó, A.I.; Vadász, C.; Kálmán, N.; Máté, A.; Malatinszky, Á. Simplicity or complexity? Important aspects of high nature value grassland management in nature conservation. Biodivers. Conserv. 2021, 30, 3563-3583. [CrossRef]

14. Ranta, M.; Rotar, I.; Vidican, R.; Mălinaș, A.; Ranta, O.; Lefter, N. Influence of the uan fertilizer application on quantitative and qualitative changes in semi-natural grassland in western Carpathians. Agronomy 2021, 11, 267. [CrossRef]

15. Dullau, S.; Rydgren, K.; Kirmer, A.; Jäger, U.G.; Meyer, M.H.; Tischew, S. The dessau grassland experiment-impact of fertilization on forage quality and species assembly in a species-rich alluvial meadow. Agriculture 2021, 11, 339. [CrossRef]

16. Chytrý, M.; Tichý, L.; Hennekens, S.M.; Knollová, I.; Janssen, J.A.M.; Rodwell, J.S.; Peterka, T.; Marcenò, C.; Landucci, F.; Danihelka, J.; et al. EUNIS Habitat Classification: Expert system, characteristic species combinations and distribution maps of European habitats. Appl. Veg. Sci. 2020, 23, 648-675. [CrossRef]

17. Chytrý, M.; Tichý, L. National vegetation classification of the Czech Republic: A summary of the approach. Phytocoenologia 2018, 48, 121-131. [CrossRef]

18. van't Veen, H.; Chalmandrier, L.; Sandau, N.; Nobis, M.P.; Descombes, P.; Psomas, A.; Hautier, Y.; Pellissier, L. A landscape-scale assessment of the relationship between grassland functioning, community diversity, and functional traits. Ecol. Evol. 2020, 10, 9906-9919. [CrossRef]

19. Hijmans, R.J.; Cameron, S.E.; Parra, J.L.; Jones, P.G.; Jarvis, A. Very high resolution interpolated climate surfaces for global land areas. Int. J. Climatol. 2005, 25, 1965-1978. [CrossRef]

20. Ewald, J. The sensitivity of Ellenberg indicator values to the completeness of vegetation relevés. Basic Appl. Ecol. 2003, 4, 507-513. [CrossRef]

21. Euro+Med. Euro+Med PlantBase-The Information Resource for Euro-Mediterranean Plant Diversity. 2006. Available online: http:/ / ww2.bgbm.org/EuroPlusMed/ (accessed on 1 September 2021).

22. Mládek, J.; Mládková, P.; Hejcmanová, P.; Dvorský, M.; Pavlu, V.; De Bello, F.; Duchoslav, M.; Hejcman, M.; Pakeman, R.J. Plant trait assembly affects superiority of grazer's foraging strategies in species-rich grasslands. PLoS ONE 2013, 8, e69800. [CrossRef]

23. Pauler, C.M.; Isselstein, J.; Suter, M.; Berard, J.; Braunbeck, T.; Schneider, M.K. Choosy grazers: Influence of plant traits on forage selection by three cattle breeds. Func. Ecol. 2020, 34, 980-992. [CrossRef]

24. Busch, V.; Klaus, V.H.; Schäfer, D.; Prati, D.; Boch, S.; Müller, J.; Chisté, M.; Mody, K.; Blüthgen, N.; Fischer, M.; et al. Will I stay or will I go? Plant species-specific response and tolerance to high land-use intensity in temperate grassland ecosystems. J. Veg. Sci. Veg. Sci. 2019, 30, 674-686. [CrossRef]

25. Bengtsson, J. Which species? What kind of diversity? Which ecosystem function? Some problems in studies of relations between biodiversity and ecosystem function. Appl. Soil Ecol. 1998, 10, 191-199. [CrossRef]

26. Luo, J.; Liu, X.; Yang, J.; Liu, Y.; Zhou, J. Variation in plant functional groups indicates land degradation on the Tibetan Plateau. Scienfific Rep. 2018, 8, 17606. [CrossRef] [PubMed]

27. Grime, J.P. Plant Strategies, Vegetation Processes, and Ecosystem Properties, 2nd ed.; Wiley: New York, NY, USA, 2001.

28. Klotz, S.; Kühn, I.; Durka, W. BIOLFLOR_Eine Datenbank zu Biologisch-Ökologischen Merkmalen der Gefäßpflanzen in Deutschland; Schriftenreihe für Vegetationskunde 38; Bundesamt für Naturschutz (BfN): Bonn, Germany, 2002.

29. Hunt, R.; Hodgson, J.; Thompson, K.; Bungener, P.; Dunnett, N.; Askwe, A. A new practical tool for deriving a functional signature for herbaceous vegetation. Appl. Veg. Sci. 2004, 7, 163-170. [CrossRef]

30. Tichý, L.; Holt, J.; Nejezchlebová, M. Juice. In Program for Management, Analysis and Classification of Ecological Data; Vegetation Science Group, Masaryk University: Brno, Germany, 2006.

31. Ellenberg, H.; Weber, H.E.; Dull, R.; Wirth, V.; Werner, W.; Paulißen, D. Zeigerwerte von Pflanzen in Mitteleuropa; Scripta Geobotanica 18, 1-285; Verlag Erich Goltze: Göttingen, Germany, 1992; ISBN 3884525182.

32. Troiani, N.; Tradella, F.M.; Malatesta, L.; Corazza, M.; Ferrari, C.; Catorci, A. Long-term cropland abandonment does not lead per se to the recovery of semi-natural herb communities deemed habitats of community interest. Acta Bot. Croat. 2016, 75, 226-235. [CrossRef]

33. StatSoft, I. Electronic Statistics Textbook; Statsoft: Tulsa, Oklahoma, 2011.

34. Lengyel, A.; Swacha, G.; Botta-Dukát, Z.; Kącki, Z. Trait-based numerical classification of mesic and wet grasslands in Poland. J. Veg. Sci. 2020, 31, 319-330. [CrossRef]

35. Čarni, A.; Ćuk, M.; Zelnik, I.; Franjić, J.; Igić, R.; Ilić, M.; Krstonošić, D.; Vukov, D.; Škvorc, Ž. Wet meadow plant communities of the alliance Trifolion pallidi on the southeastern margin of the Pannonian plain. Water 2021, 13, 381. [CrossRef]

36. Grime, J.P. Trait convergence and trait divergence in herbaceous plant communities: Mechanisms and consequences. J. Veg. Sci. 2006, 17, 255-260. [CrossRef]

37. Horvatić, S. Soziologische Einheiten der Niederungswiesen in Kroatien und Slavonien. Acta Bot. Croat. 1930, 5, 57-118.

38. Szépligeti, M.; Kőrösi, Á.; Szentirmai, I.; Házi, J.; Bartha, D.; Bartha, S. Evaluating alternative mowing regimes for conservation management of Central European mesic hay meadows: A field experiment. Plant Biosyst. 2018, 152, 90-97. [CrossRef]

39. Swacha, G.; Botta-Dukát, Z.; Kącki, Z.; Pruchniewicz, D.; Zołnierz, L. The effect of abandonment on vegetation composition and soil properties in Molinion meadows (SW Poland). PLoS ONE 2018, 13, e0197363. [CrossRef] [PubMed] 
40. Edwards, K.R.; Kučera, T. Management effects on plant species composition and ecosystem processes and services in a nutrientpoor wet grassland. Plant Ecol. 2019, 220, 1009-1020. [CrossRef]

41. Müller, I.B.; Buhk, C.; Alt, M.; Entling, M.H.; Schirmel, J. Plant functional shifts in Central European grassland under traditional flood irrigation. Appl. Veg. Sci. 2016, 19, 122-131. [CrossRef]

42. Dwire, K.A.; Kauffman, J.B.; Brookshire, E.N.J.; Baham, J.E. Plant biomass and species composition along an environmental gradient in montane riparian meadows. Oecologia 2004, 139, 309-317. [CrossRef]

43. Hoover, D.L.; Knapp, A.K.; Smith, M.D. Resistance and resilience of a grassland ecosystem to climate extremes. Ecology 2014, 95, 2646-2656. [CrossRef]

44. Valkó, O.; Török, P.; Matus, G.; Tóthmérész, B. Is regular mowing the most appropriate and cost-effective management maintaining diversity and biomass of target forbs in mountain hay meadows? Flora-Morphol. Distrib. Funct. Ecol. Plants 2012, 207, 303-309. [CrossRef]

45. Prins, H.H.T.; Ydenberg, R.C.; Drent, R.H. The interaction of Brent Geese Branta bernicla and Sea Plantain Plantago maritima during spring staging: Field observations and experiments. Acta Bot. Neerl. 1980, 29, 585-596. [CrossRef]

46. Gaberščik, A.; Krek, J.L.; Zelnik, I. Habitat diversity along a hydrological gradient in a complex wetland results in high plant species diversity. Ecol. Eng. 2018, 118, 84-92. [CrossRef]

47. Bruelheide, H.; Dengler, J.; Purschke, O.; Lenoir, J.; Jiménez-Alfaro, B.; Hennekens, S.M.; Botta-Dukát, Z.; Chytrý, M.; Field, R.; Jansen, F.; et al. Global trait-environment relationships of plant communities. Nat. Ecol. Evol. 2018, 2, 1906-1917. [CrossRef]

48. Grime, J.P. Evidence for the existence of three primary strategies in plants and its relevance to ecological and evolutionary theory. Am. Nat. 1977, 111, 1169-1194. [CrossRef]

49. Hellström, K.; Huhta, A.-P.; Rautio, P.; Tuomi, J.; Oksanen, J.; Laine, K. Use of sheep grazing in the restoration of semi-natural meadows in northern Finland. Appl. Veg. Sci. 2003, 6, 45-52. [CrossRef]

50. Chelli, S.; Marignani, M.; Barni, E.; Petraglia, A.; Puglielli, G.; Wellstein, C.; Acosta, A.T.R.; Bolpagni, R.; Bragazza, L.; Campetella, G.; et al. Plant-Environment interactions through a functional traits perspective: A review of Italian studies. Plant Biosyst. 2019, 153, 853-869. [CrossRef]

51. Slavnić, Ž. Slatinska vegetacija Vojvodine. Arh. Za Poljopr. Nauk. I Teh. 1948, 3, 77-143.

52. Čarni, A. Staudenfluren-und Ufervegetation (Verbände Filipendulion Segal 1966 und Senecion fluviatilis R. Tx. (1947)1950 em. 1967) im Krško Becken. Biološki Vestn. 1995, 40, 71-85.

53. Dindová, A.; Hakl, J.; Hrevušová, Z.; Nerušil, P. Relationships between long-term fertilization management and forage nutritive value in grasslands. Agric. Ecosyst. Environ. 2019, 279, 139-148. [CrossRef]

54. Pierik, M.E.; Gusmeroli, F.; Della Marianna, G.; Tamburini, A.; Bocchi, S. Meadows species composition, biodiversity and forage value in an Alpine district: Relationships with environmental and dairy farm management variables. Agric. Ecosyst. Environ. 2017, 244, 14-21. [CrossRef]

55. Tzialla, C.E.; Veresoglou, D.S.; Papakosta, D.; Mamolos, A.P. Changes in soil characteristics and plant species composition along a moisture gradient in a Mediterranean pasture. J. Environ. Manag. 2006, 80, 90-98. [CrossRef]

56. Kim, S.-H.; Kim, T.-K. Economic valuation of multi-functionality on an eco-pastoral system in Alpine grassland. J. Korean Soc. Grassl. Forage Sci. 2018, 38, 298-309. [CrossRef]

57. Kaligarič, M.; Ivanjšič, D. Vanishing landscape of the "classic" Karst: Changed landscape identity and projections for the future Landsc. Urban Plan. 2014, 132, 148-158. [CrossRef]

58. Prach, K. Vegetation Changes in a wet meadow complex during the past half-century. Folia Geobot. 2008, 43, 119-130. [CrossRef]

59. Kaligarič, M.; Čuš, J.; Škornik, S.; Ivajnšič, D. The failure of agri-environment measures to promote and conserve grassland biodiversity in Slovenia. Land Use Policy 2019, 80, 127-134. [CrossRef]

60. Isbell, F.; Tilman, D.; Reich, P.; Clark, A. Deficits of biodiversity and productivity linger a century after agricultural abandonment. Nat. Ecol. Evol. 2019, 3, 1533-1538. [CrossRef] [PubMed] 